\title{
Stormwater Pond Sediment Loading and Accumulation Analysis
}

\section{Michael A. Gregory}

\begin{abstract}
The permanent pool in stormwater detention facilities is designed for water quality treatment by providing an appropriate storage volume for the settling of the suspended solids and particulate matter that are carried in stormwater runoff. The facility may include additional storage components designed to provide erosion and flood control, but it is the layout and configuration of the permanent pool volume that typically dictates the overall pond footprint size. Sizing of the permanent pool volume is often based on local regulatory requirements that dictate a prescribed total suspended solids (TSS) removal rate, expressed as a percentage removal on an average annual basis. The volume requirement is typically given as a function of the imperviousness and area of the tributary catchment. It is presumed that a pond that meets or exceeds the required volume will achieve its TSS removal target. The actual treatment efficiency of the pond is a function of catchment hydrology (of which imperviousness is just one of many variables), control structure hydraulics, and the particle size distribution of TSS in stormwater runoff. After the pond has been constructed it is also important for the owner or operator of the pond to understand the sediment loading and accumulation characteristics, given the high cost of sediment removal. Presumptive design criteria used to size the permanent pool of stormwater ponds do not account for these site specific characteristics. To overcome the limitations inherent in presumptive design criteria, a modeling and design methodology using SWMM5 was developed to estimate the sediment loading and accumulation rate for a facility in Ontario, Canada.
\end{abstract}

Keywords: stormwater detention facilities, total suspended solids (TSS), particle size distribution, treatment efficiency.

\section{Background}

In November, 2011 the City of Hamilton, Ontario retained AECOM to provide consulting engineering services related to the design, permitting and construction of the Twenty Road regional stormwater management facility. This facility is located on city owned property, a 2.2 ha (5.4 acre) parcel southeast of the intersection of Twenty Road and the future Dartnall Road extension, designed to service 36 ha ( 89 acre) of future development on primarily commercial and industrial lands.

The stormwater servicing design includes infrastructure for collecting and managing stormwater to minimize flooding and erosion hazards, as well as to maximize water quality treatment and environmental benefits in the downstream receiving watercourses of Hannon Creek, which ultimately discharges into Lake Ontario.

Figure 1 shows the layout and configuration for the pond design. There are two piped inlets discharging to the forebay that will serve future developments to the east and west. A deflection berm was designed to improve the settling and dispersion of the particulate pollutants that remain in the stormwater runoff after treatment in the forebay (by increasing the hydraulic residence time from the forebay to the outlet). The permanent pool elevation in both the forebay and main cell of the pond are shown in light grey in the figure.

Two rip-rap lined channels direct major system overflows into the pond from the east and west, bypassing the forebay. The figure also shows the maintenance access route (dark gray) and planting shelf around the pond perimeter, as well as the sediment decant and drying area along the south edge of the property. The primary outfall discharges into a receiving watercourse located northwest of the pond, and a secondary pond outfall discharges to the northeast for the purpose of providing supplementary inflows for a relocated watercourse (in order to maintain the existing flow regime) as part of the site development in the adjacent property to the east.

The analysis and design efforts undertaken during this project were subject to stringent deadlines. Fieldwork and model setup began in December 2011, and the final design and permitting was completed in June 2012. This project required ongoing design coordination with others on adjacent properties, including roadway extensions, watercourse relocations and significant site development of an industrial property to be serviced by the pond. The modeling efforts developed as part of this study served as the basis for gauging the cumulative impacts on receiving watercourses throughout the study area. Construction began in 


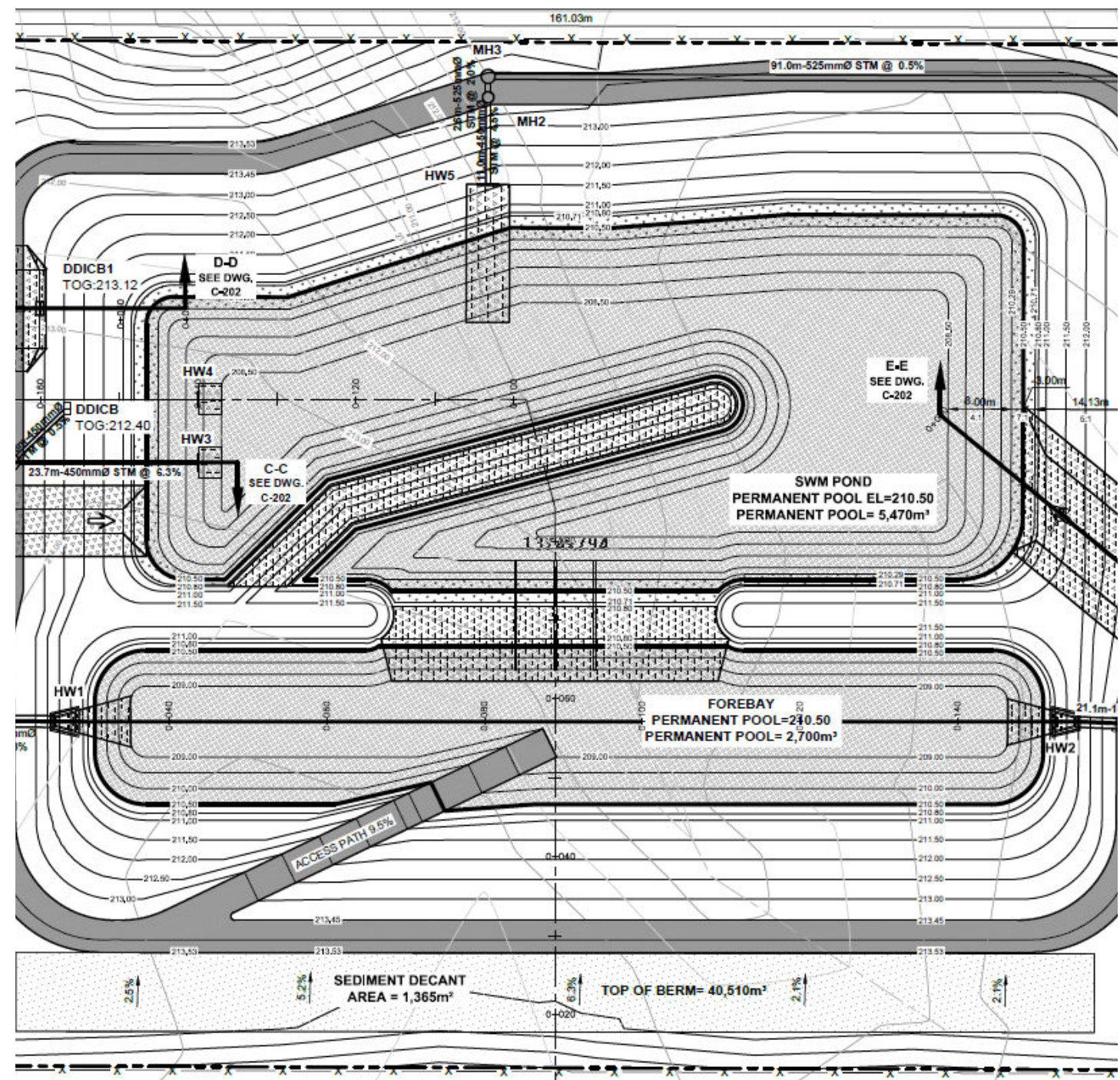

Figure 1 Plan view of stormwater detention facility design (not to scale).

October 2012 and was completed in early 2013. Figure 2 shows a photo of the pond in January 2013 (looking southeast).

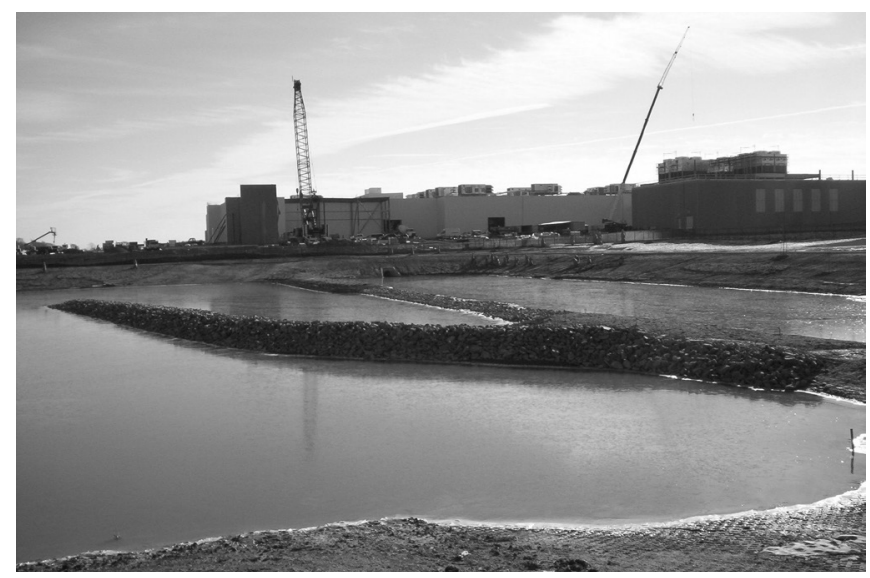

Figure 2 Stormwater detention facility during construction (photo courtesy of the City of Hamilton).

\section{Model Development (Event Based Simulation)}

The latest version of SWMM5 (build 5.0.022, released April 2011) was used to simulate the stormwater runoff response under existing and proposed land use conditions, and to analyze and optimize the pond design.

\subsection{Hydrologic Model}

Stormwater facilities were designed using a traditional event based hydrology approach, which is most appropriate for flood control where the design objective is to collect and dispose of runoff in a manner that protects public safety and minimizes property damage during extreme events. The sizing of the major and minor collection system, pond control structures and outlet works adheres to the local municipal and provincial design standards, which quantify criteria for a range of defined design storm events that include: 
- baseflow event featuring $15 \mathrm{~mm}$ rainfall over $24 \mathrm{~h}$ duration, which corresponds to a 1 month return period;

- water quality control volume event featuring $25 \mathrm{~mm}$ rainfall over $24 \mathrm{~h}$ duration, which corresponds to a 3 month return period;

- 2 y return period $24 \mathrm{~h}$ duration event with $53.1 \mathrm{~mm}$ rain;

- 5 y $24 \mathrm{~h}$ event with $71.8 \mathrm{~mm}$ rain;

. 10 y $24 \mathrm{~h}$ event with $84.2 \mathrm{~mm}$ rain;

- 25 y $24 \mathrm{~h}$ event with $99.8 \mathrm{~mm}$ rain;

100 y 24 h event with $122.9 \mathrm{~mm}$ rain; and

the regional storm event, Hurricane Hazel, represented by a rainfall depth of $285 \mathrm{~mm}$ over a $48 \mathrm{~h}$ period. This event features $212 \mathrm{~mm}$ of rainfall over a $12 \mathrm{~h}$ period, preceded by $73 \mathrm{~mm}$ rainfall over a period of $36 \mathrm{~h}$.

The hydrologic model was developed using lumped parameters in which average representative values were determined for each hydrologic unit (or subcatchment) tributary to the proposed pond. Overland flow parameters describe the slope and length characteristics of shallow surface runoff. Representative overland flow paths were identified for each hydrologic unit. The overland flow path slope was taken as the grade difference of the land surface along the overland flow path. Overland flow path lengths were divided into the subcatchment area to give a characteristic width of overland flow, which is a SWMM5 input parameter.

Surface cover parameters describe the imperviousness, roughness and depression storage characteristics. Various surface cover types were defined in order to reflect the unique hydrologic properties within each subcatchment. These were selected in consideration of the TSS buildup and washoff characteristics that also vary by surface cover type, as discussed below for water quality. The surface cover types include:

- Forest: forest or meadow, heavy vegetation with high transpiration rates and a deep root zone;

- Grass: grass or turf, light vegetation, cultivated or landscaped areas with a shallow root zone;

- Farm: cultivated agricultural fields;

- Bare: unvegetated soil, loose granular materials, or legacy compacted fill;

- GrnRoof: building structures with vegetated roof;

- RegRoof: building structures with regular rooftop construction and materials;

- PrmPave: permeable paved surfaces with underdrain system;

- ImpPave: regular impermeable paved surfaces (roadways, parking, driveways);

- Gravel: gravel and compacted granular in traffic areas;

- Wetland: hydrologic parameters reflect an area that is roughly half open water and half heavily vegetated; and
- Water: open water surface, including detention facilities.

Surface cover types were interpreted using aerial photography of the site. Characteristic hydrologic properties were assigned to each surface cover type as shown in Table 1, based on literature values (e.g. Bedient and Huber 1992; Chow et al. 1988) and adapted for use in many watershed master planning and design studies throughout North America.

Table 1 Summary of hydrologic properties (by surface cover type).

\begin{tabular}{|c|c|c|c|c|c|c|c|c|}
\hline & \multicolumn{2}{|c|}{ Manning's " $n$ " } & \multicolumn{2}{|c|}{ Dep. Storage $(\mathrm{mm})$} & \multirow{2}{*}{$\begin{array}{c}\% \\
\text { Imperv- } \\
\text { ious }\end{array}$} & & & \multirow{2}{*}{$\begin{array}{c}\% \text { Imperv } \\
\text { Without } \\
\text { Storage }\end{array}$} \\
\hline $\begin{array}{c}\text { Surface Cover } \\
\text { Type }\end{array}$ & $\begin{array}{c}\begin{array}{l}\text { Imperv- } \\
\text { ious }\end{array} \\
\text { ins }\end{array}$ & Pervious & \begin{tabular}{|c|}
$\begin{array}{c}\text { Imperv- } \\
\text { ious }\end{array}$ \\
\end{tabular} & Pervious & & \begin{tabular}{|l|} 
Subarea \\
Routing
\end{tabular} & $\begin{array}{c}\% \% \\
\text { Routed }\end{array}$ & \\
\hline Forest & 0.030 & 0.400 & 10.0 & 15.0 & 1 & Pervious & 100 & 10 \\
\hline Grass & 0.025 & 0.250 & 5.0 & 10.0 & 2.5 & Pervious & 75 & 10 \\
\hline Farm & 0.025 & 0.350 & 5.0 & 10.0 & 5 & Pervious & 75 & 10 \\
\hline Bare & 0.020 & 0.150 & 5.0 & 7.5 & 5 & Pervious & 50 & 10 \\
\hline GrnRoof & 0.025 & 0.300 & 17.5 & 20.0 & 25 & Pervious & 25 & 15 \\
\hline RegRoof & 0.015 & 0.150 & 2.5 & 5.0 & 95 & Pervious & 10 & 25 \\
\hline PrmPave & 0.020 & 0.200 & 12.5 & 15.0 & 50 & Pervious & 25 & 15 \\
\hline ImpPave & 0.015 & 0.150 & 2.5 & 5.0 & 95 & Pervious & 10 & 20 \\
\hline Gravel & 0.025 & 0.200 & 5.0 & 7.5 & 90 & Pervious & 25 & 20 \\
\hline Wetland & 0.015 & 0.350 & 0.0 & 15.0 & 50 & Pervious & 50 & 10 \\
\hline Water & 0.015 & 0.015 & 0.0 & 0.0 & 100 & Pervious & 0 & 0 \\
\hline
\end{tabular}

For each surface cover type, the following hydrologic parameters are given:

- overland flow roughness factors, expressed as Manning's $n$ value, for both impervious and pervious fractions;

- initial abstractions (i.e. depression storage losses) for both impervious and pervious fractions;

- percentage of impervious cover, including any land surface that has been compacted or is covered with a layer of material such that it substantially reduces or prevents the infiltration of stormwater runoff into the ground;

- subarea routing is a SWMM5 simulation parameter that designates the internal routing of runoff between pervious and impervious areas (in this case, Pervious was selected to indicate a portion of runoff from impervious areas can be discharged onto pervious areas);

- percent routed indicates the portion of runoff that is routed between subareas (e.g. 100\% indicates that all of the impervious area in the subcatchment is routed onto pervious surfaces); and

- the final column indicates the fraction of impervious area that has no depression storage.

Table 2 shows the distribution of surface cover within each hydrologic unit, expressed as a percentage of the total subcatchment area, under proposed conditions. When these proportions are cross-multiplied by the global parameters in Table 1, the resulting area-weighted surface cover parameters are calculated for each hydrologic unit. The bottom row shows the area-weighted average values throughout the study area. Note that only the hydrologic units named with the prefixes "Pr_" or "ML_" are tributary to the stormwater pond. 
Table 2 Distribution of surface cover types (by hydrologic unit).

\begin{tabular}{|c|c|c|c|c|c|c|c|c|c|}
\hline \multirow{2}{*}{$\begin{array}{l}\text { Hydrologic } \\
\text { Unit Name }\end{array}$} & \multicolumn{9}{|c|}{ Percent By Surface Cover Type } \\
\hline & Forest & Grass & Farm & RegRoof & ImpPave & Gravel & Wetland & Water & Total \\
\hline Ex_10 & $15.6 \%$ & $55.0 \%$ & $13.3 \%$ & $3.1 \%$ & $10.1 \%$ & $0.8 \%$ & & $2.2 \%$ & $100.0 \%$ \\
\hline Ex_12m & $5.2 \%$ & & $82.8 \%$ & $0.4 \%$ & $11.2 \%$ & & & $0.4 \%$ & $100.0 \%$ \\
\hline Ex_13 & & $8.6 \%$ & $88.5 \%$ & $2.9 \%$ & & & & & $100.0 \%$ \\
\hline Ex_14 & $20.2 \%$ & & $79.8 \%$ & & & & & & $100.0 \%$ \\
\hline Ex_15m & & & $76.0 \%$ & & $24.0 \%$ & & & & $100.0 \%$ \\
\hline Ex_16 & $9.3 \%$ & & $83.5 \%$ & & & & $7.2 \%$ & & $100.0 \%$ \\
\hline Ex_16Am & & & $75.2 \%$ & & $24.8 \%$ & & & & $100.0 \%$ \\
\hline Ex $16 \mathrm{Bm}$ & $1.6 \%$ & & $94.1 \%$ & & $4.3 \%$ & & & & $100.0 \%$ \\
\hline Pr_1 & & $11.0 \%$ & & $37.0 \%$ & $47.0 \%$ & $5.0 \%$ & & & $100.0 \%$ \\
\hline Pr_2 & & $11.0 \%$ & & $37.0 \%$ & $47.0 \%$ & $5.0 \%$ & & & $100.0 \%$ \\
\hline Pr_3 & & $12.0 \%$ & & $31.0 \%$ & $42.0 \%$ & & & $15.0 \%$ & $100.0 \%$ \\
\hline Pr_4 & $23.0 \%$ & & $20.0 \%$ & & $36.0 \%$ & $21.0 \%$ & & & $100.0 \%$ \\
\hline ML_1 & & $32.9 \%$ & & $45.7 \%$ & $21.4 \%$ & & & & $100.0 \%$ \\
\hline $\mathrm{ML}=2$ & & $49.2 \%$ & & $0.0 \%$ & $50.8 \%$ & & & & $100.0 \%$ \\
\hline ML_3 & & $20.5 \%$ & & $57.8 \%$ & $21.7 \%$ & & & & $100.0 \%$ \\
\hline ML_4 & & $20.4 \%$ & & $72.6 \%$ & $7.0 \%$ & & & & $100.0 \%$ \\
\hline ML_5 & & $0.0 \%$ & & $86.6 \%$ & $13.4 \%$ & & & & $100.0 \%$ \\
\hline ML_6 & & $27.0 \%$ & & $52.0 \%$ & $21.0 \%$ & & & & $100.0 \%$ \\
\hline ML 7 & & $14.3 \%$ & & $7.2 \%$ & $78.5 \%$ & & & & $100.0 \%$ \\
\hline $\mathrm{ML} \_8$ & & $16.6 \%$ & & $46.4 \%$ & $37.0 \%$ & & & & $100.0 \%$ \\
\hline ML_9 & & $100.0 \%$ & & $0.0 \%$ & $0.0 \%$ & & & & $100.0 \%$ \\
\hline ML_10 & & $100.0 \%$ & & $0.0 \%$ & $0.0 \%$ & & & & $100.0 \%$ \\
\hline ML_11 & & $100.0 \%$ & & $0.0 \%$ & $0.0 \%$ & & & & $100.0 \%$ \\
\hline ML_12 & & $100.0 \%$ & & $0.0 \%$ & $0.0 \%$ & & & & $100.0 \%$ \\
\hline aHC0011 & & & $92.3 \%$ & & $7.7 \%$ & & & & $100.0 \%$ \\
\hline $\mathrm{aHC} 0011 \mathrm{a} 3$ & $7.3 \%$ & $3.8 \%$ & $73.8 \%$ & & $2.4 \%$ & $1.4 \%$ & $11.3 \%$ & & $100.0 \%$ \\
\hline Area-wtd Avg: & $3.2 \%$ & $12.4 \%$ & $39.8 \%$ & $18.3 \%$ & $22.1 \%$ & $1.4 \%$ & $0.9 \%$ & $2.0 \%$ & $100.0 \%$ \\
\hline
\end{tabular}

Infiltration parameters were determined for the Green-Ampt method in SWMM5 based on soil texture properties, including:

- capillary tension, a measure of how tightly water is held within the soil pore space;

- saturated hydraulic conductivity, a measure of how quickly the water can be drained vertically; and

- porosity (or initial soilwater deficit), the volumetric fraction of water within the soil pore space under initially dry conditions.

Soil texture was based on the geotechnical investigations undertaken as part of the adjacent site development, which included $>30$ boreholes across the site and two within the proposed location for the stormwater detention facility. These investigations indicated that surficial soils are consistently silty clay throughout the site.

\subsection{Hydraulic Model}

The hydraulic model was developed using available field survey and topographical data to characterize the conveyance and routing of stormwater throughout the existing drainage network. The drainage network was represented by a link-node system of conduits (culverts, pipes, open watercourses and road overflows) and junctions (storage areas, connecting nodes and outfalls). The model includes a representation of the collection system tributary to the proposed pond, significant storage features within the subject site, the pond and its related control structures, and the connection of the pond outfalls to the downstream receiving watercourses.

A fixed tailwater elevation was assigned to the outfall as the boundary condition that varied for each design storm event. For non-outfall junctions, these values were projected horizontally through the system to determine the corresponding initial flow depth. The initial flow depth for junctions tributary to the pond were based on the normal pool elevation (210.50 m).
The storage volume in the forebay and main cell of the proposed pond was combined and represented as a single storage unit in SWMM5. Surface flooding in the upstream collection system was noted for the larger design storm events. As a result, surface storage was added to the locations of inundation and connecting conduits were added to route major system surface flows into the pond.

\section{Stormwater Management Servicing De- sign}

The design criteria used to size the proposed pond and corresponding control structures was based on achieving the following:

- consistency with design standards (City of Hamilton 2007);

- water quality treatment: enhanced level of protection as designated by the provincial guidelines (Ontario Ministry of the Environment 2003);

- water quantity control: post-development peak flow rates discharged from the stormwater facility do not exceed pre-development rates for the $2 \mathrm{y}$ through $100 \mathrm{y}$ return period design storm events and the regional storm event must be safely conveyed to the receiving watercourse; and

- erosion hazard mitigation: erosion protection measures at the primary and secondary outfalls, which includes rock and stone treatments sized to provide resistive forces in excess of the tractive forces resulting from $100 \mathrm{y}$ return period flows.

Detention facility volume components and control structure features can be classified by various pond storage components as described below.

\subsection{Permanent Pool}

The permanent pool was sized to provide an appropriate water quality treatment volume based on provincial requirements that achieve an enhanced protection level, which is presumed to provide $80 \%$ suspended solids removal rate on an average annual basis. The required water quality treatment volume varies by the imperviousness of the tributary area. A portion of the permanent pool volume is included in the forebay at the south end of the facility, which receives minor flows from the two pond inlets and is shaped to enhance initial settling of suspended solids.

A permanent pool elevation of $210.50 \mathrm{~m}$ will be maintained by the invert elevation of a reverse sloped bottom-draw. This elevation is coincident with the gate valve used to control the extended detention volume. The permanent pool has a maximum depth of $2.00 \mathrm{~m}$, with a pond bottom elevation of $208.50 \mathrm{~m}$.

Design details include:

- permanent pool elevation: $210.50 \mathrm{~m}$;

- surface area (at permanent pool elevation, forebay plus main cell): $6600 \mathrm{~m}^{2}$; 
- required permanent pool volume: $7000 \mathrm{~m}^{3}$ (195 $\mathrm{m}^{3} /$ ha, for $76 \%$ imperviousness of the tributary area to the pond); and

- available permanent pool volume: $8200 \mathrm{~m}^{3}$, which exceeds the required volume (note this assumes the maximum permanent pool depth of $2 \mathrm{~m}$ throughout the main cell).

It is not recommended that the pond footprint be reduced to match the required permanent pool volume as the additional storage volume above the permanent pool is critical to achieving the pre-development peak flows for the larger design storm events.

\subsection{Extended Detention}

The volume component above the permanent pool is referred to in this paper as extended detention, which has multiple functions in controlling downstream flows from the higher frequency (smaller volume) rainfall events. This component has also been referred to as live storage, suggesting its role in water quantity control (i.e. typically for rainfall events with a return period of $\leq 5 \mathrm{y})$ However, extended detention also provides additional water quality treatment and streambank erosion protection.

Runoff in this component is controlled by means of a gate valve. The sizing of an equivalent orifice diameter for the valve was optimized to achieve the $2 \mathrm{y}$ through $100 \mathrm{y}$ pre-development discharge, and to ensure that runoff from the water quality event will not be completely discharged in $<24 \mathrm{~h}$. The top of the extended detention volume is indicated by the quality overflow elevation of $212.40 \mathrm{~m}$, which is controlled by the lowest grate elevation of a ditch inlet catchbasin. The quality overflow elevation is coincident with the $10 \mathrm{y}$ design high water level. This provides an extra level of erosion protection should the secondary outfall controls be inoperable due to clogging by debris, for example.

Design details include:

- water quality gate valve setting (equivalent orifice diameter): $225 \mathrm{~mm}$ (crest elevation at $210.50 \mathrm{~m}$ );

- quality overflow elevation: 212.40 m (1.90 m above permanent pool); and

- available extended detention volume: $17800 \mathrm{~m}^{3}$, or approximately $495 \mathrm{~m}^{3} / \mathrm{ha}$.

\subsection{Flood Control}

In this paper, flood control storage refers to the volume component above the extended detention storage and serves to mitigate water quantity impacts downstream of the facility for the lower frequency (larger volume) rainfall events. While some water quantity control is provided in the extended detention component below, the primary function of this upper component is flood control.

Runoff in this component will be controlled by means of the water quantity orifice plate attached to the outlet pipe. The top of the flood control volume is marked by the top of the embankment and is controlled by an emergency spillway crest that is set $0.3 \mathrm{~m}$ below the top of berm (i.e. emergency overflow elevation of $213.22 \mathrm{~m}$, which is $\geq 0.1 \mathrm{~m}$ above the $100 \mathrm{y}$ design high water level, according to the city standard).

The sizing of the quantity orifice was optimized to achieve the 100 y pre-development discharge and to ensure that the $100 \mathrm{y}$ high water level in the pond remains $\geq 0.1 \mathrm{~m}$ below the emergency overflow elevation. The spillway was designed to provide flood control conveyance for the regional storm event, within acceptable depth and velocity limits. That is, spillway flows for this extreme event do not exceed a depth of $0.25 \mathrm{~m}$ or a velocity of $2.0 \mathrm{~m} / \mathrm{s}$.

Design details include:

- water quantity orifice diameter: $300 \mathrm{~mm}$;

. primary outfall pipe diameter: $750 \mathrm{~mm}$;

- quantity overflow elevation: $213.22 \mathrm{~m}$;

top of embankment elevation: 213.52 m (3.02 m above permanent pool);

- available flood control volume (at the overflow elevation): $10300 \mathrm{~m}^{3}$, or approximately $287 \mathrm{~m}^{3} / \mathrm{ha}$; and

- reserve flood control volume (to top of embankment): $4200 \mathrm{~m}^{3}$.

The emergency spillway was designed to convey excess runoff from the regional storm event through the roadside ditch along the eastern right-of-way of Dartnall Road. The emergency spillway includes an overflow channel with characteristics that were represented as follows:

- length: $10 \mathrm{~m}$ (across the access road);

. height: $0.3 \mathrm{~m}$ (to the top of the berm);

- bottom width: $10 \mathrm{~m}$ (crest elevation corresponds to the quantity overflow elevation of $213.22 \mathrm{~m}$ ); and sideslopes: 10:1.

\subsection{Secondary Outfall}

The control structures described above discharge to the primary outfall (west tributary) and were sized to provide water quality and quantity objectives for future development that will be serviced by the pond. A secondary outfall discharges to the east tributary and was sized to achieve the supplementary inflows specified for the receiving watercourse, using two orifices to limit flows through the outfall pipe. This tributary also receives treated stormwater from the portion of the adjacent development site that is not serviced by the Twenty Road pond. Details for this outfall include:

- secondary outfall pipe diameter: $525 \mathrm{~mm}$;

- water quantity orifice 1 diameter: $140 \mathrm{~mm}$ (crest elevation at $211.50 \mathrm{~m}$ ); and

- water quantity orifice 2 diameter: $450 \mathrm{~mm}$ (crest elevation at $212.38 \mathrm{~m}$ ).

\section{Model Development (Continuous Simu- lation)}

The previous sections summarize the modeling methodology and design approach to meet local standards involving event based 
simulation. This section describes how the model was adapted for continuous simulation.

\subsection{Model Applications Using Continuous Simu- lation}

Continuous hydrologic simulation requires long term meteorological input that encompasses a range of historical rainfall events as well as the dry weather periods in between, not just selected design storms that characterize extreme events. It can complement the sizing of stormwater infrastructure by addressing the full range of runoff response characteristics, from the common rainfall events that are commensurate with the day-to-day stormwater facility operations, as well as chemical and biological functions and physical processes in the receiving waters, to the extreme events embodied in current drainage design and floodplain management practices.

Among the many benefits of continuous simulation, it is possible to evaluate the hydraulic performance of existing stormwater systems under a broad range of flow regimes, rather than just snapshots of performance indicators for selected design storm events. Only long term (multi-year) continuous simulation can achieve design objectives that involve:

- maintaining baseflows in receiving watercourses;

- maintaining appropriate water level fluctuations in wetlands:

- groundwater recharge and discharge and water supply and wellhead protection; and

- natural habitat impacts.

For this project, continuous simulation was used in order to meet specific requirements of the permitting agencies, including:

1. Erosion threshold analysis: Erosion hazard impacts to the downstream watercourses can be addressed by performing a flow frequency analysis of peak velocity results, and comparing these to the critical erosive velocity thresholds that were defined as part of the geomorphology assessment for this project. Sustained flows that exceed the defined thresholds would require watercourse improvements to protect against erosion. Velocity frequency curves derived from continuous simulation were used to optimize the stormwater detention facility design to achieve the defined erosion thresholds. Results confirmed that the extended detention storage volume was sufficient to reduce the peak velocities discharged;

2. Vegetation selection: A pond drawdown analysis was conducted to determine the time to release the flood control and extended detention volume components of the pond. In addition, a depth duration analysis was performed using continuous simulation to facilitate vegetation selection for the landscaping plan. Figure 3 shows the total time duration that pond stages are exceeded. For example, vegetation planted along the water's edge (water level
$210.50 \mathrm{~m}$ ) can expect an inundation depth of $50 \mathrm{~cm}$ (water level $211.00 \mathrm{~m}$ ) 3\% of the time. This information assisted the landscape architect's selection as the analysis accounts for the delayed drawdown times following real storm events, rather than the peak pond depths during design storm events which cannot be correlated to biological activity;

3. Future development source controls: Onsite stormwater retention facilities would likely be required for future development upstream of the pond. These may include infiltration trenches or galleries, bioretention cells, green roofs or cisterns for irrigation, and equipment and vehicle washing or other non-potable uses. Water balance controls are implicit in low impact development (LID) design, which is intended to manage runoff volumes in an attempt to maintain predevelopment hydrologic conditions. One advantage of continuous simulation is that it better expresses the proportion of hydrologic components, compared to design storm events where water balance proportions are necessarily biased toward rare events (Gregory and Arseneau 2012); and

4. Sediment loading and accumulation analysis: This is described in detail in Section 5.



Figure 3 Depth duration analysis of pond water levels.

\subsection{Model Adjustments for Continuous Simula- tion}

In addition to the design storm events listed in Section 2.1, longterm rainfall records were applied. Local archival tipping bucket gauge data (with at least a 5 min resolution) were not available for use in this study. Long term tipping bucket rainfall data were available from the Elora Research Station, operated by the University of Guelph, located approximately $50 \mathrm{~km}$ (30 miles) from the project site. A total of 22 y tipping bucket data ( 1 min resolution) was acquired from the Elora station, representing the period of record from 1989 through 2010. This rain gauge is not operated 
during the winter months and therefore only data from April through October was used as input for continuous simulation. Consequently, snowmelt was not considered in the analysis.

The rainfall records used for continuous simulation in this study include:

- 1989-2010: the complete Elora period of record dataset; and

- average year: a composite dataset developed from the Elora dataset comprising selected data over the rainfall season (April through October); representative months were selected based on the total monthly rainfall in any given year that was closest to the long term station average at the Hamilton airport.

Table 3 compares these rainfall records with the Environment Canada reported climate normals for the most recent meteorological epoch (1971-2000) at the airport. These values are for rainfall only, and do not include snowfall equivalent amounts in the late spring and early fall months. The first row shows the 22 y Elora station average monthly totals from the composite average year Elora record, along with the dataset year that was used (in parentheses). The second row lists the corresponding airport monthly totals, followed by the difference between the average year and the local rainfall monthly totals. Overall, the designated average year data used in this study is within $1 \%$ of the total amount representing the airport rainfall year.

Table 3 Rainfall record comparison

\begin{tabular}{|c|r|r|r|r|r|r|r|c|}
\hline Rainfall Record & \multicolumn{1}{c|}{ Apr } & \multicolumn{1}{c}{ May } & \multicolumn{1}{c}{ Jun } & \multicolumn{1}{c|}{ Jul } & Aug & Sep & Oct & Total \\
\hline $\begin{array}{c}\text { Elora Research Station } \\
\text { "Average Year" }\end{array}$ & $\begin{array}{r}69.6 \\
(1995)\end{array}$ & $\begin{array}{r}74.2 \\
(1994)\end{array}$ & $\begin{array}{r}84.2 \\
(2002)\end{array}$ & $\begin{array}{r}90.4 \\
(1996)\end{array}$ & $\begin{array}{r}81.0 \\
(2005)\end{array}$ & $\begin{array}{r}81.4 \\
(1992)\end{array}$ & $\begin{array}{r}70.8 \\
(1993)\end{array}$ & $\mathbf{5 5 1 . 6}$ \\
\hline $\begin{array}{c}\text { Hamilton Airport } \\
1971-2000 \text { (Climate Normals) }\end{array}$ & 69.6 & 75.0 & 83.9 & 86.5 & 80.6 & 82.1 & 71.6 & $\mathbf{5 4 9 . 3}$ \\
\hline Difference & $0 \%$ & $-1 \%$ & $0 \%$ & $5 \%$ & $0 \%$ & $-1 \%$ & $-1 \%$ & $\mathbf{0 \%}$ \\
\hline
\end{tabular}

Evaporation during the intense short duration design storm events is negligible and is typically ignored in the sizing of stormwater management infrastructure and facilities. For continuous simulation however, evaporation is a significant hydrologic variable and cannot be ignored. Evaporation from all storage junctions including the pond was also simulated in the model.

In this study, evaporation data were input into the hydrologic model as a daily abstraction rate for each calendar month in the continuous simulation runs, including the following values during the simulation period:

- April: $1.1 \mathrm{~mm} / \mathrm{d}$;

May: $2.0 \mathrm{~mm} / \mathrm{d}$;

June: $4.9 \mathrm{~mm} / \mathrm{d}$;

July: $5.2 \mathrm{~mm} / \mathrm{d}$;

- August: $4.9 \mathrm{~mm} / \mathrm{d}$;

September: $3.3 \mathrm{~mm} / \mathrm{d}$; and

- October: $2.3 \mathrm{~mm} / \mathrm{d}$.

These values represent a total potential evaporation of $725 \mathrm{~mm}$ over the rainfall year (April through October). The total potential evaporation for all months in the calendar year matches the annual lake evaporation rate of $813 \mathrm{~mm}$ for Lake Ontario at Toronto.

Seasonal fluctuations in groundwater levels can also affect the performance of stormwater management facilities. The geotechnical investigations undertaken as part of the adjacent site development indicated that seasonal fluctuations of groundwater levels would not impact the performance of the pond. Consequently, groundwater impacts were not considered as part of the continuous simulation analysis.

\section{Sediment Loading and Accumulation}

The permanent pool was sized to provide an appropriate water quality treatment volume based on provincial requirements that achieve an enhanced level of protection presumed to provide an $80 \%$ suspended solids removal rate on an average annual basis. After the model was adapted for continuous simulation, it was applied to confirm the long term suspended solids removal efficiency would be achieved and also to estimate sediment loading and accumulation volumes for the city's future pond cleanout operations. A monitoring program to collect water quality data and determine the actual removal efficiency has not yet been conducted.

\subsection{Model Methodology}

The water quality module of SWMM5 was used to simulate the generation of TSS loadings from each subcatchment tributary to the pond, including pollutant buildup during dry weather periods and washoff during rainfall events. The pollutographs were subsequently routed through the collection system and the deposition of particulate solids in the pond was simulated.

The process for simulating TSS loading into the collection system first required the categorization of surface cover types to generate the pollutant loads. Next, the appropriate parameters were assigned to the buildup and washoff functions that determine the pollutant loadings from each surface cover type. The only source of TSS represented in the model is from surface washoff. That is, contributions from rainfall, groundwater or other sources were not considered.

In SWMM5, particulate settling can be represented by a characteristic settling velocity distribution. No local stormwater settling velocity measurements were available and so empirical data from other regions were used from the Nationwide Urban Runoff Program (NURP, referenced in USEPA 1983). Six mass fractions were used to characterize the particle size distribution of the stormwater washoff load and these are shown in Table 4. For each mass fraction, the equivalent particle diameter range and mean are shown along with the average particle density and dry bulk density. 
Table 4 Suspended solids characteristics.

\begin{tabular}{|r|r|r|r|r|}
\hline \multirow{2}{*}{$\begin{array}{c}\text { Mass } \\
\text { Fraction }\end{array}$} & \multicolumn{2}{|l|}{ Equiv. Diameter $(\mu \mathrm{m})$} & \multirow{2}{*}{$\begin{array}{c}\text { Density } \\
\left(\mathrm{kg} / \mathrm{m}^{3}\right)\end{array}$} & $\begin{array}{c}\text { Bulk Density } \\
\text { Dry }\left(\mathrm{kg} / \mathrm{m}^{3}\right)\end{array}$ \\
\hline $0-20 \%$ & $<3$ & 1.5 & 2,200 & 200 \\
\hline $20-30 \%$ & $3-5$ & 4 & 2,425 & 400 \\
\hline $30-40 \%$ & $5-7$ & 6 & 2,425 & 400 \\
\hline $40-60 \%$ & $7-17$ & 12 & 2,575 & 1,200 \\
\hline $60-80 \%$ & $17-35$ & 26 & 2,650 & 1,800 \\
\hline $80-100 \%$ & $>35$ & 103 & 2,650 & 1,800 \\
\hline
\end{tabular}

\subsection{Buildup and Washoff Characteristics}

The parameters describing the buildup and washoff of TSS are shown in Table 5. Suspended solids loadings for each subcatchment were determined using the same surface cover types that were defined for the hydrology model described in Section 2.1. The buildup of TSS that accumulates within each land use category was represented using the power function option in SWMM5. With this function, the pollutant buildup is expressed by a rate that increases proportionally by the number of preceding dry weather days until a maximum accumulation mass is achieved.

Input parameters for the power buildup function include:

- maximum buildup rate, expressed as a limiting mass per unit subcatchment area;

- buildup rate constant, expressed as a mass per unit area per day input for each size fraction; and

- power constant used to characterize the time exponent in the buildup equation.

Table 5 Buildup and washoff parameters for total suspended solids.

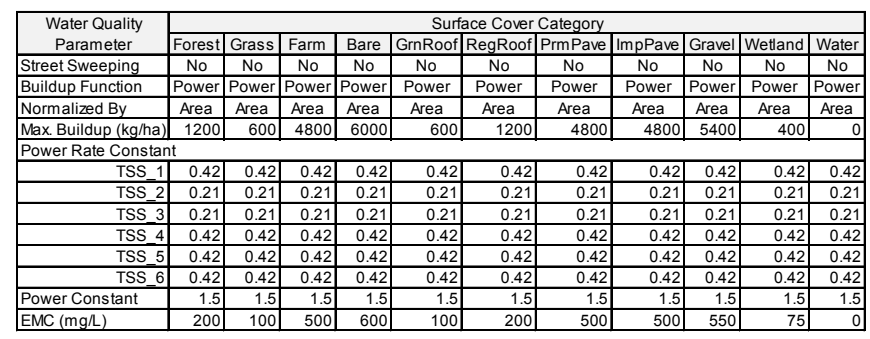

The buildup of accumulated TSS becomes available for washoff into the collection system. Washoff of TSS was represented using the Event Mean Concentration (EMC) option in SWMM5. With this option, the pollutant washoff is expressed as a constant washoff pollutant concentration in mass per liter. During wet weather events, these concentrations are sustained until the accumulated buildup mass is depleted at which time washoff ceases. The washoff EMC rates were defined individually by surface cover type and shown in the final row of Table 5. No local TSS measurements were available to calibrate the buildup and washoff functions; therefore parameters were estimated from the range of values reported in the literature.

\subsection{Particulate Settling}

To represent the deposition of particulates in the pond, a treatment expression based on settling velocity was developed for each mass fraction of TSS. The treatment expression defines the rate of particulate settling as a function of time and depth of water in the pond. The mass of TSS that settles out is removed from the water column.

Table 6 shows the settling velocities for each size fraction along with the corresponding treatment expressions reported in the NURP study (USEPA 1983) and subsequently adapted for use in detention facility sizing (USEPA 1985). The treatment expressions are input directly into SWMM5, using the variables as shown $(C=$ concentration; Depth = settling depth; and DT = computational timestep). The residual TSS concentration in the pond was assumed to be zero for all size fractions.

Table 6 Particulate settling velocities and treatment expressions.

\begin{tabular}{|c|c|c|c|c|c|}
\hline \multirow{2}{*}{$\begin{array}{c}\text { Size } \\
\text { Fraction }\end{array}$} & \multirow{2}{*}{$\begin{array}{c}\% \text { Finer } \\
\text { Than } \\
\end{array}$} & \multirow{2}{*}{$\begin{array}{l}\text { Mass } \\
\text { Fraction }\end{array}$} & \multicolumn{2}{|c|}{ Average Velocity } & \multirow{2}{*}{ Treatment Expression } \\
\hline & & & $(\mathrm{m} / \mathrm{s})$ & (fthr) & \\
\hline TSS_1 & $20 \%$ & $20 \%$ & 0.0000025 & 0.03 & * $\operatorname{EXP}\left(-0.00000254 / \mathrm{DEPTH}{ }^{*} \mathrm{DT}\right)$ \\
\hline TSS_2 & $30 \%$ & $10 \%$ & 0.0000130 & 0.15 & $C=\operatorname{TSS} 2 * \operatorname{EXP}(-0.00001300 / \mathrm{DEPTH} * \mathrm{DT})$ \\
\hline TSS_3 & $40 \%$ & $10 \%$ & 0.0000254 & 0.30 & $C=\operatorname{TSS} 3 * \operatorname{EXP}(-0.00002540 / D E P T H * D T)$ \\
\hline TSS 4 & $60 \%$ & $20 \%$ & 0.0001270 & 1.50 & $C=\operatorname{TSS} 4 * \operatorname{EXP}(-0.00012700 / D E P T H * D T)$ \\
\hline TSS 5 & $80 \%$ & $20 \%$ & 0.0005927 & 7.00 & $C=\operatorname{TSS} 5 * \operatorname{EXP}(-0.00059267 / \mathrm{DEPTH} * \mathrm{DT})$ \\
\hline$\overline{T S S \_6}$ & $100 \%$ & $20 \%$ & 0.0055033 & 65.00 & $=\operatorname{TSS} 6 * \operatorname{EXP}(-0.00550333 / \mathrm{DEPTH} * \mathrm{DT})$ \\
\hline
\end{tabular}

\subsection{Model Results and Discussion}

The model was applied to the average year rainfall described in Section 4.2, which is representative of the local average annual conditions. Figure 4 shows the simulated TSS concentrations for the smallest and largest size fractions (TSS_1 and TSS_6 respectively) within the water column of the pond. The differences in particulate removal rates are evident by comparing the two pollutographs, with the lighter particles remaining in the water column for a longer duration after each rainfall event (smallest size fraction) and the heavier particles settling out quickly (largest size fraction).



Figure 4 Average year TSS concentration in pond. 
Results of the sediment loading and accumulation analysis are presented in Table 7. The sediment characteristics of the particulate mass fractions are shown at the top of the table. The first two rows show the surface washoff loading into the pond along with the TSS load that is discharged from the pond for an average rainfall year (i.e. April through October). The resulting removal efficiencies are shown in the third row, which highlights the preferential transport of smaller particles (i.e. lower removal efficiency for the smallest size fraction) and the preferential settling of larger particles (i.e. nearly $100 \%$ efficiency for the largest size fraction). The total TSS washoff loading rate is approximately $920 \mathrm{~kg} / \mathrm{ha} / \mathrm{y}(\sim 820 \mathrm{lb} / \mathrm{acre} / \mathrm{y})$, which is at the upper end of the range reported in the literature for highly urbanized areas (Harper 1994; SWFWMD 1989).

Table 7 Sediment loading and accumulation results.

\begin{tabular}{|c|c|c|c|c|c|c|c|}
\hline Event/Particle Characteristic & \multicolumn{6}{|c|}{ TSS Loading and Accumulation by Particle Size } & \multirow{6}{*}{$\begin{array}{l}\text { Total } \\
\text { TSS } \\
\text { Loading }\end{array}$} \\
\hline Mass Fraction (\% Finer Than): & $0-20 \%$ & $20-30 \%$ & $30-40 \%$ & $40-60 \%$ & $60-80 \%$ & $80-100 \%$ & \\
\hline Equivalent Particle Size: & $<3 \mu \mathrm{m}$ & $3-5 \mu \mathrm{m}$ & $5-7 \mu \mathrm{m}$ & $7-17 \mu \mathrm{m}$ & $17-35$ & $>35 \mu \mathrm{m}$ & \\
\hline Mean Equivalent Diameter: & $1.5 \mu \mathrm{m}$ & $4 \mu \mathrm{m}$ & $6 \mu \mathrm{m}$ & $12 \mu \mathrm{m}$ & $26 \mu \mathrm{m}$ & $103 \mu \mathrm{m}$ & \\
\hline Equiv. Particle Density $\left(\mathrm{kg} / \mathrm{m}^{3}\right)$ : & 2,200 & 2,425 & 2,425 & 2,575 & 2,650 & 2,650 & \\
\hline Equiv. Dry Bulk Density $\left(\mathrm{kg} / \mathrm{m}^{3}\right)$ : & 200 & 400 & 400 & 1,200 & 1,800 & 1,800 & \\
\hline Surface Washoff L & 6,765 & 3,011 & 3,011 & 6,765 & 6,765 & 6,765 & 33,083 \\
\hline Pond Discharge Load $(\mathrm{kg})$ & 2,535 & 510 & 374 & 350 & 69 & & 3,844 \\
\hline Removal Efficiency & $62.5 \%$ & $83.1 \%$ & $87.6 \%$ & $94.8 \%$ & $99.0 \%$ & $99.9 \%$ & $88.4 \%$ \\
\hline in in Pond (kol) & 4,230 & 2,501 & 2,637 & 6,415 & 6,696 & 6,760 & 29,239 \\
\hline Volume Remaining in Pond $\left(\mathrm{m}^{3}\right)$ & 21.1 & 6.3 & 6.6 & 5.3 & 3.7 & 3.8 & 46.8 \\
\hline
\end{tabular}

Overall, the pond removal efficiency is $88 \%$ on an average annual basis, which achieves the presumptive design criteria for an enhanced level of water quality protection. The last two rows show the TSS loads and corresponding volumes (based on dry bulk density) that remain in the pond at the end of the rainfall year.

The average sediment volume is $47 \mathrm{~m}^{3}$, which corresponds to an accumulation rate of $1.3 \mathrm{~m}^{3} / \mathrm{ha} / \mathrm{y}\left(\sim 18.7 \mathrm{ft}^{3} / \mathrm{acre} / \mathrm{y}\right)$ for the non-winter period of April through October. Note that SWMM5 does not reduce the available storage volume in the pond by the amount of accumulated sediment. In this case, the sediment volume amounts to less than $1 \%$ of the permanent pool volume, which is considered negligible.

Snowmelt and hydrologic conditions during winter months were not included in this analysis. In addition to the washoff loads generated by land surfaces, winter road operations may introduce additional TSS loading for the winter months of November through March. As a conservative estimate, the computed accumulation rate for the non-winter period was assumed also for the winter months, giving an estimated annual sediment accumulation rate of $2.6 \mathrm{~m}^{3} / \mathrm{ha} / \mathrm{y}\left(37.4 \mathrm{ft}^{3} / \mathrm{acre} / \mathrm{y}\right)$. The estimated sediment accumulation volume over a $10 \mathrm{y}$ period is $940 \mathrm{~m}^{3}$, which can be accommodated within the available sediment decant volume of $1230 \mathrm{~m}^{3}$.

\section{Conclusions}

The sizing of stormwater management facilities across North America largely relies on event based hydrologic modeling methods, which continue to be prescribed in local stormwater design guidelines. However, event based methods cannot be used to suf- ficiently assess the water quality treatment performance of such facilities. In lieu of monitoring, only continuous simulation can be used to assess the long term average annual TSS removal from a stormwater detention facility.

To overcome the limitations inherent in presumptive design criteria, a modeling methodology was developed that improves the current state-of-the-practice design methods. This method was applied to a recently permitted and constructed pond in Ontario. A key feature of this method involves representing the catchment hydrology based on source area delineations that distinguish specific surface cover types to characterize the generation of TSS loads across a range of urban land uses.

The water quality module of SWMM5 was used to simulate the generation of TSS loadings from all source areas tributary to the pond, including pollutant buildup during dry weather periods and washoff during rainfall events for a representative average year of rainfall. The pollutographs were subsequently routed through the collection system and the deposition of particulate solids in the pond was simulated. The TSS removal efficiency and annual sediment accumulation rates were then estimated.

\section{References}

Bedient, P. B. and W. C. Huber. 1992. Hydrology and Floodplain Analysis, 2nd ed. Lebanon, IN: Addison-Wesley. ISBN 0-20151711-6.

Chow, V. T., D. R. Maidment and L. W. Mays. 1988. Applied Hydrology. New York: McGraw-Hill. ISBN 0-07-010810-2.

City of Hamilton. 2007. Criteria and Guidelines for Stormwater Infrastructure Design. Burlington, Ontario: Philips Engineering Ltd.

Environment Canada. 2008. Canadian Climate Normals 1971-2000. Ottawa: Environment Canada National Climate Data and Information Archive. http://climate.weather.gc.ca/index_e. html.

Gregory, M. and D. Arseneau. 2012. "Design, Construction and Hydraulic Performance Assessment of an Infiltration Gallery." Journal of Water Management Modeling R245-10. doi: 10.14796/JWMM.R245-10.

Harper, H. H. 1994. Stormwater Loading Rate Parameters for Central and South Florida. Orlando, FL: Environmental Research \& Design Inc. (ERD).

Ontario Ministry of the Environment. 2003. Stormwater Management Planning and Design Manual. Toronto: Queen's Printer for Ontario. ISBN 0-7794-2969-9.

SWFWMD (Southwest Florida Water Management District). 1989. Estimation of Loading Rate Parameters for the Tampa Bay Watershed. Brooksville, FL: Southwest Florida Water Management District.

USEPA. 1983. Results of the Nationwide Urban Runoff Program: Volume 1-Final Report. Washington, DC: U.S. Environmental 
Protection Agency, Water Planning Division. Publication 832-R-83-112.

USEPA. 1985. Methodology for Analysis of Detention Basins for Control of Urban Runoff Quality. Washington, DC: U.S. Environmental Protection Agency, Water Planning Division. Publication 440-5-87-001.

Michael A. Gregory AECOM, Kitchener, Ontario.
USEPA. 2010. Storm Water Management Model User's Manual, Version 5.0. Washington, DC: U.S. Environmental Protection Agency. Publication 600-R-05-040. 